\title{
Strategies for the evaluation of interventions for the control of tuberculosis: integrative review
}

\author{
Estratégias de avaliação das intervenções para o controle de tuberculose: revisão integrativa
}

Estrategias de evaluación de las intervenciones para el control de la tuberculosis: revisión integrativa

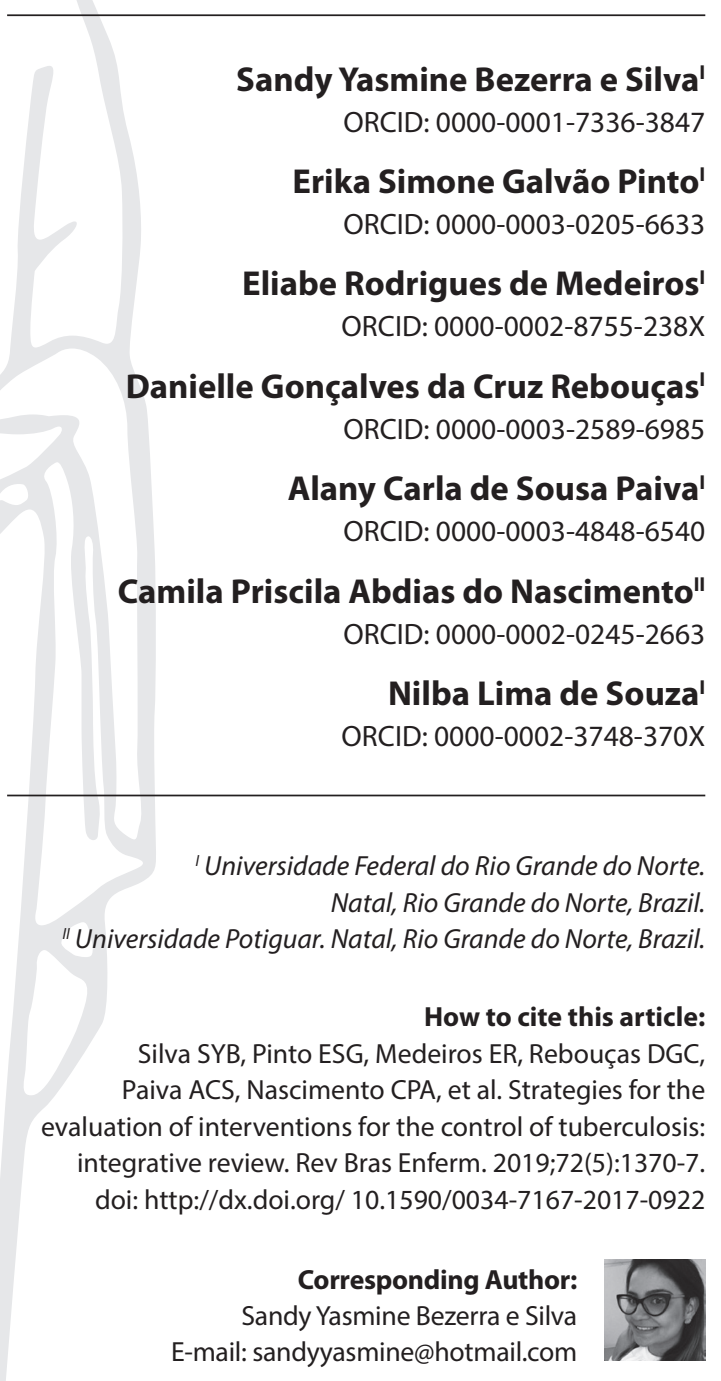

Submission: 12-11-2017

Approval: 03-05-2018

\section{ABSTRACT}

Objective: Identifying the available evidence in the scientific literature about the strategies used in the evaluations of interventions for the control of tuberculosis. Method: Integrative review with searches in databases Lilacs, CINAHL and PubMed in August 2017. Thirty-three articles were selected and the theoretical referential of health assessment was used for analysis. Results: The prevalent interventions were health programs (60.7\%), 69.7\% focusing on results and $81.9 \%$ having quantitative character $(81.9 \%$ ). Final considerations: The evaluation of interventions for the control of tuberculosis is beneficial for the health services' users and aids in the decision making of managers and health professionals.

Descriptors: Tuberculosis; Evaluation; Health Assessment; Evaluation of Health Programs and Projects; Review.

\section{RESUMO}

Objetivo: Identificar as evidências disponíveis na literatura científica sobre as estratégias utilizadas nas avaliações das intervenções para o controle da tuberculose. Método: Revisão integrativa com buscas nas bases de dados Lilacs, CINAHL e PubMed no mês de agosto de 2017. Foram selecionados 33 artigos e para análise foi utilizado o referencial teórico de avaliação em saúde. Resultados: As intervenções prevalentes foram programas de saúde $(60,7 \%)$, com69,7\% focando resultados e $81,9 \%$ apresentando caráter quantitativo $(81,9 \%)$. Considerações finais: A avaliação das intervenções para o controle da tuberculose auxilia a população usuária dos serviços de saúde e a tomada de decisões pelos gestores e profissionais de saúde.

Descritores: Tuberculose; Avaliação; Avaliação em Saúde; Avaliação de Programas e Projetos de Saúde; Revisão.

\section{RESUMEN}

Objetivo: Identificar las evidencias disponibles en la literatura científica sobre las estrategias utilizadas en las evaluaciones de las intervenciones para el control de la tuberculosis. Método: Revisión integrativa con búsquedas en las bases de datos Lilacs, CINAHL y PubMed en el mes de agosto de 2017. Se seleccionaron 33 artículos, y para el análisis se utilizó el referencial teórico de evaluación en salud. Resultados: Las intervenciones que prevalecieron fueron programas de salud $(60,7 \%)$, con un $69,7 \%$ enfocando resultados y un $81,9 \%$ presentando carácter cuantitativo $(81,9 \%)$. Consideraciones finales: La evaluación de las intervenciones para el control de la tuberculosis ayuda a la población usuaria de los servicios de salud y a la toma de decisiones por los gestores y profesionales de la salud. Descriptores: Tuberculosis; Evaluación en salud; Evaluación de Programas y Proyectos de Salud; Revisión. 


\section{INTRODUCTION}

Tuberculosis (TB) is considered a disease of international health concern. In 2016, about 10.4 million people got sick from TB and 6.3 million new cases were diagnosed in the whole world. Despite 53 million deaths having been avoided between 2000 and 2016 and their mortality rates and incidence having reduced in $2 \%$ and $3 \%$ per year, respectively, TB is the ninth leading cause of death in the world ${ }^{(1)}$.

The control of TB is sought for and encouraged through the End Tuberculosis Strategy created by the Member States of the World Health Organization (WHO). To eradicate the disease throughout the world, it is expected that, from 2015 to $2030,90 \%$ of its deaths and $80 \%$ of its incidence are reduced ${ }^{(1)}$.

Several countries have joined this strategy through the adoption of targets that meet the proposed objective, although they have had policies to this end since WHO declared the disease as being in state of emergency in the $1990 \mathrm{~s}^{(1)}$. An example of this are the treatments offered to people with TB in the United States of America at the Centers for Disease Control and Prevention ${ }^{(2)}$, and the National Tuberculosis Control Program in Brazil, created in $1999^{(3)}$.

However, these and other interventions may be influenced by contextual factors that compromise their implementation, which can be identified through health assessment, characterized by provision of information that contributes to the decision making of managers and health professionals ${ }^{(4)}$.

Understanding the strategies used for this purpose can encourage evaluative studies relating to TB control programs, in addition to subsidizing the practice of health professionals in the evaluation of Primary Health Care Services.

\section{OBJECTIVE}

Identifying the available evidence in the scientific literature about the strategies used in the evaluations of interventions for the control of tuberculosis.

\section{METHOD}

\section{Ethical aspects}

Because it is methodology that analyzes data that has already been ethically published and analyzed, consideration by the Research Ethics Committee was not needed.

\section{Study design}

An integrative literature review consists of a research method that gathers and synthesizes the results of previous studies in a systematic and rigorous manner. For preparation of this integrative review, the following steps were followed: definition of the guiding question; search in the literature; extraction of data from the selected studies; evaluation of the studies and summary of the results; discussion and presentation of the integrative review(5).

\section{Population, inclusion and exclusion criteria}

Articles published between 2012 and 2017, available in full for free in English, Spanish and Portuguese, which addressed the proposed theme, were included. Editorials, letters to the editor, review studies, theses, dissertations, repeated articles and studies that did not address the theme relevant to the purpose of this review were excluded.

\section{Study protocol}

For the elaboration of the guiding question of the integrative review, the PICO strategy was used ${ }^{(6)}$, where P (problem) corresponds to Tuberculosis, I (intervention) to Interventions for TB control, C (control) does not apply to this proposal and $\mathrm{O}$ (outcome) refers to the evaluation of interventions for TB control. The guiding question thus was: what is the available evidence about the strategies used in the evaluations of interventions for TB control?

The search for the studies was held in August of 2017 in the portal of journals of the Coordination of Higher Education and Graduate Training (Capes), with access through the Federated Academic Community (CAFe) which the researchers are part of. The research encompassed the following databases: Latin American and Caribbean Center on Health Sciences Information (Lilacs), Cumulative Index to Nursing and Allied Health Literature (CINAHL), ScienceDirect and US National Library of Medicine (PubMed).

As research strategy, the Health Sciences Descriptors (DeCS) for the databases in Portuguese and the corresponding Medical Subject Headings (MeSH) for those in English were used, allied to the Boolean operators and or, enabling the following combinations: "Tuberculose and Avaliação em Saúde or Avaliação de Programas e Projetos de Saúde" and "Tuberculosis and Health Evaluation or Program Evaluation".

The search and selection of the studies followed the criteria recommended by the PRISMA group ${ }^{(7)}$ and was conducted simultaneously by two researchers. In situations of disagreement, a consensus was sought for with the participation of an auxiliary researcher. A protocol was previously created to guide the development of the study.

Figure 1 describes the search process:

\begin{tabular}{|c|c|c|}
\hline \multirow{2}{*}{ Identification } & $\begin{array}{r}\text { Records identified in the databases: ScienceDirect }(\mathrm{n} \\
=234), \text { Lilacs }(\mathrm{n}=6), \mathrm{CINAHL}(\mathrm{n}=3,363) \text {, PubMed }(\mathrm{n} \\
=5,448) \text {. Total: } 9,051 .\end{array}$ \\
\hline Selection & \multicolumn{2}{|c|}{ Duplicate records removed ( $\mathrm{n}=5)$} \\
\hline \multirow{2}{*}{ Eligibility } & $\begin{array}{r}\text { Selected records } \\
(\mathrm{n}=9,046)\end{array}$ & $\begin{array}{c}\text { Excluded records } \\
(\mathrm{n}=8,996)\end{array}$ \\
\cline { 2 - 3 } & $\begin{array}{c}\text { Full-text articles assessed } \\
\text { as eligible ( } \mathrm{n}=45)\end{array}$ & $\begin{array}{c}\text { Full-text articles } \\
\text { excluded, with reasons } \\
(\mathrm{n}=12)\end{array}$ \\
\hline Inclusion & Studies included in the qualitative summary ( $\mathrm{n}=33)$ \\
\hline
\end{tabular}




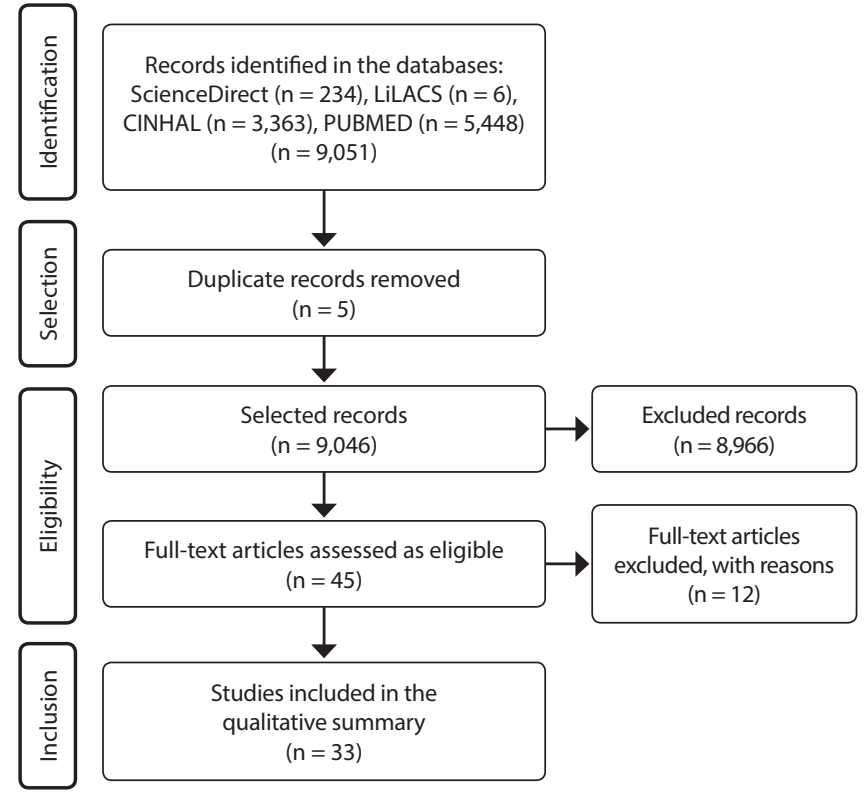

Figure 1 - Search flow chart, 2017

The first selection of articles happened through the reading of the titles and abstracts; then, the articles were read in their entirety and the information obtained was distributed in tables and charts, with subsequent categorization of data.

\section{Analysis of the results}

For analysis of the information, a spreadsheet created in Microsoft Excel ${ }^{\oplus}$ was used, consisting of the items: database, journal, language, year of publication, methodological approach used, type of evaluation, country where the intervention was performed, dimension of evaluation (structure, process and result) according to the classification by Avedis Donabedian ${ }^{(8)}$, evaluation level, characteristics of the intervention, theme and type of evaluation proposed.

In this way, the result is defined as a very practical assessment approach, that is also more accurate. Despite indicating whether care is good or bad, the result does not encompass the nature and location of the shortcomings or strengths, and considers that the evaluation approach is concerned with examining the means, and not the power of a technology only. Furthermore, when defining the structure, it designates under what conditions the instruments which it is product of occur, and is concerned about the adequacy of facilities, equipment and organization ${ }^{(8)}$.

The evaluation levels can be divided in four generations. The first is characterized by measurement and would be associated with performance evaluation, using instruments that measure intelligence, productivity and others. The second encompasses the identification and description of the process. The third is based on judgement, where the evaluator performs the function of describing, measuring and establishing the merits of the program. Finally, the fourth generation is based on an inclusive and participatory evaluation, called negotiation ${ }^{(9)}$.

The evaluation provides benefits to health practices, becoming relevant when coupled with the possibility and the need for interventions that are able to modify certain sanitary contexts. Therefore, it is understandable that the interventions may constitute an object of evaluation in their more complex levels such as programs, policies, services, or systems ${ }^{(4)}$.

\section{RESULTS}

The search resulted in 33 articles that met the criteria for inclusion proposed. Most publications included were found in PubMed (51.5\%), followed by Lilacs (15.1\%). The description of the selected articles is presented in Chart 1.

Chart 1 - Description of articles on the evaluation of interventions for the control of tuberculosis, according to author, year, country, language, type of approach, theme, type of intervention and the intervention's characteristics, 2017

\begin{tabular}{|l|c|c|c|l|}
\hline \multicolumn{1}{|c|}{ Author, year, country } & Language & Approach & Intervention & Description \\
\hline $\begin{array}{l}\text { Wilson et al., 2016(10) } \\
\text { El Salvador }\end{array}$ & English & Qualitative & Project & Health education strategy \\
\hline $\begin{array}{l}\text { Alkhalawi et al., 2016(11) } \\
\text { Saudi Arabia }\end{array}$ & English & Quantitative & Program & Investigation of contacts; public TB surveillance system \\
\hline $\begin{array}{l}\text { Guzzetta et al., 2015(12) } \\
\text { United States }\end{array}$ & English & Quantitative & Program & Investigation of contacts \\
\hline $\begin{array}{l}\text { Roque-Henríquez et al., 2015(13) } \\
\text { Peru }\end{array}$ & Spanish & Quantitative & Program & Implementation of TB control activities \\
\hline $\begin{array}{l}\text { Mendonça, 2015 } \\
\text { Brazil }\end{array}$ & Portuguese & Quantitative & Program & Implementation of TB control activities \\
\hline $\begin{array}{l}\text { García de la Rosa et al., 2014(15) } \\
\text { Cuba }\end{array}$ & Spanish & Quantitative & Program & Investigation of contacts \\
\hline $\begin{array}{l}\text { Lima et al., 2013(16) } \\
\text { Brazil }\end{array}$ & Portuguese & Quantitative & Program & Investigation of contacts \\
\hline $\begin{array}{l}\text { Heck et al., 2013(17) } \\
\text { Brazil }\end{array}$ & Portuguese & Quantitative & Program & Implementation of TB control activities \\
\hline $\begin{array}{l}\text { Arakawa et al., 2017(18) } \\
\text { Brazil }\end{array}$ & Portuguese & Quantitative & Program & Implementation of TB control activities \\
\hline
\end{tabular}


Chart 1 (concluded)

\begin{tabular}{|c|c|c|c|c|}
\hline Author, year, country & Language & Approach & Intervention & Description \\
\hline $\begin{array}{l}\text { Karki et al., } 2017^{(19)} \\
\text { Papua New Guinea }\end{array}$ & English & Quantitative & Services & Screening of TB cases \\
\hline $\begin{array}{l}\text { Dharan et al., } 2016^{(20)} \\
\text { United States }\end{array}$ & English & Quantitative & Examination & $\begin{array}{l}\text { Detection of resistance to the drugs used in the } \\
\text { treatment of TB }\end{array}$ \\
\hline $\begin{array}{l}\text { McLaren et al., } 2016^{(21)} \\
\text { South Africa }\end{array}$ & English & Quantitative & System & Measurement of population risk factors for TB \\
\hline $\begin{array}{l}\text { Georghiou et al., 2016 } \\
\text { Multicenter }\end{array}$ & English & Quantitative & Examination & TB diagnosis \\
\hline $\begin{array}{l}\text { Galarza et al., } 2016^{(23)} \\
\text { Peru }\end{array}$ & English & Quantitative & Examination & $\begin{array}{l}\text { Detection of resistance to the drugs used in the } \\
\text { treatment of TB }\end{array}$ \\
\hline $\begin{array}{l}\text { Tans-Kersten et al., 2016 } \\
\text { United States }\end{array}$ & English & Quantitative & Services & $\begin{array}{l}\text { Diagnosis and detection of resistance to drugs used in } \\
\text { the treatment of TB shared by laboratory services }\end{array}$ \\
\hline $\begin{array}{l}\text { Long et al., } 2015^{(25)} \\
\text { Canada }\end{array}$ & English & Quantitative & Program & Implementation of TB control activities \\
\hline $\begin{array}{l}\text { De Grass et al., 2014 } \\
\text { South Africa }\end{array}$ & English & Quantitative & Program & Pulmonary home rehabilitation \\
\hline $\begin{array}{l}\text { Chua et al., } 2015^{(27)} \\
\text { Singapore }\end{array}$ & English & Quantitative & Service & Provision of financial incentive \\
\hline $\begin{array}{l}\text { Wang et al., } 2015^{(28)} \\
\text { Thailand }\end{array}$ & English & Quantitative & Examination & $\begin{array}{l}\text { Detection of resistance to the drugs used in the } \\
\text { treatment of TB }\end{array}$ \\
\hline $\begin{array}{l}\text { Azman et al., } 2014^{(29)} \\
\text { India, China and South Africa }\end{array}$ & English & Quantitative & Service & Detection and screening of TB cases \\
\hline $\begin{array}{l}\text { Birch et al., } 2014^{(30)} \\
\text { Denmark }\end{array}$ & English & Quantitative & Program & Implementation of TB control activities \\
\hline $\begin{array}{l}\text { Blaya et al., } 2014^{(31)} \\
\text { Peru }\end{array}$ & English & Quantitative & Program & $\begin{array}{l}\text { Laboratory information system to reduce delays in } \\
\text { results and errors }\end{array}$ \\
\hline $\begin{array}{l}\text { Turk et al., } 2013^{(32)} \\
\text { Pakistan }\end{array}$ & English & Quantitative & Program & $\begin{array}{l}\text { Use of a legal, communication and social mobilization } \\
\text { framework for national TB programs }\end{array}$ \\
\hline $\begin{array}{l}\text { Cass et al., } 2013^{(33)} \\
\text { United States }\end{array}$ & English & Quantitative & Program & Implementation of TB control activities \\
\hline $\begin{array}{l}\text { Yang et al., } 2012^{(34)} \\
\text { China }\end{array}$ & English & Quantitative & Program & Implementation of TB control activities \\
\hline $\begin{array}{l}\text { Khan et al., } 2015^{(35)} \\
\text { Canada }\end{array}$ & English & Quantitative & Program & Screening of TB cases \\
\hline $\begin{array}{l}\text { Yasin et al., } 2015^{(36)} \\
\text { Turkey }\end{array}$ & English & Qualitative & Program & Implementation of TB control activities \\
\hline $\begin{array}{l}\text { Velayutham et al., } 2015^{(37)} \\
\text { India }\end{array}$ & English & Quantitative & System & TB notification system \\
\hline $\begin{array}{l}\text { Salyer et al., } 2015^{(38)} \\
\text { Haiti }\end{array}$ & English & Quantitative & Program & TB notification system \\
\hline $\begin{array}{l}\text { Podewils et al., } 2015^{(39)} \\
\text { South Africa }\end{array}$ & English & Quantitative & System & National TB Surveillance System \\
\hline $\begin{array}{l}\text { Van Kampen et al., } 2015^{(40)} \\
\text { Indonesia }\end{array}$ & English & Quantitative & Examination & $\begin{array}{l}\text { Diagnosis and detection of resistance to the drugs } \\
\text { used in the treatment of TB }\end{array}$ \\
\hline $\begin{array}{l}\text { Oliveira et al., 2015 } \\
\text { Brazil }\end{array}$ & Portuguese & Quantitative & Program & Implementation of TB control activities \\
\hline
\end{tabular}

The 33 selected studies were published between 2012 and 2017 , with $42.5 \%$ having been published in 2015, 21.2\% in 2016 and $6.0 \%$ in 2017. In relation to language, 27 studies were published in English (81.9\%), 4 in Portuguese (12.1\%) and only 2 in Spanish (6.0\%). Most (94.0\%) used a quantitative approach as methodology used for data collection.

Regarding the location in which the interventions were performed, there was a predominance of studies from the American continent $(51.8 \%)$, followed by Asia (27.3\%). Interventions from
Africa $(9.0 \%)$, Europe $(3.1 \%)$ and Oceania $(3.1 \%)$ were also included. Two interventions (6.0\%) were multicenter.

As for the typology of the interventions, programs were the most prevalent $(60.7 \%)$, followed by diagnostic tests and detection of resistance to drugs used in the treatment (15.1\%), tuberculosis assistance services (12.1\%), and a reduced amount of systems $(9.1 \%)$ and projects (3.0\%).

The description of the selected articles regarding the health evaluation aspects are presented in Chart 2. 
Chart 2 - Description of the articles on the evaluation of interventions for the control of tuberculosis, according to the type of evaluation, dimension evaluated and evaluation level, 2017

\begin{tabular}{|c|c|c|}
\hline Type of evaluation & Dimension evaluated & Evaluation level \\
\hline $\begin{array}{l}\text { Performance }(11-14,18,22-23,25,32,34) \\
\text { Effects }^{(17,26-27,30,40)} \\
\text { Process }^{(15-16)} \\
\text { Impact }^{(20,31,35-36)} \\
\text { Quality }^{(11,38)} \\
\text { Deployment }^{(10,41)} \\
\text { Integrity and reliability }^{(39)} \\
\text { Efficiency }^{(28)} \\
\text { Results }^{(33)} \\
\text { Feasibility and effectiveness }^{(21,37)} \\
\text { Cost and impact }^{(29)} \\
\text { Cost and effectiveness }^{(24)}\end{array}$ & $\begin{array}{l}\text { Process }^{(11,15,19,37)} \\
\text { Result }^{(12,14,17-18,20-34,36,38-40)} \\
\text { Structure and result }{ }^{(13)} \\
\text { Process and result } \\
\text { Structure and process }\end{array}$ & $\begin{array}{l}\text { Measure }^{(13)} \\
\text { Description }^{(11,23,26,40)} \\
\text { Judgment }^{(10-12,15-22,24-25,27-39,41)} \\
\text { Negotiation }^{(14)}\end{array}$ \\
\hline
\end{tabular}

Considering that the evaluations of the interventions were classified according to their dimension, most focused on results (69.7\%). A reduced amount of studies assessed the process' dimension only $(12.1 \%)$ or more than one dimension of evaluation (18.2\%).

The analysis of the researches also allowed classifying them in relation to the level of evaluation employed. With this, $81.9 \%$ of the studies performed the judgement proposed in the third level of evaluation, while the evaluations at the measurement, description and negotiation levels were less frequent $(3 \%, 12.1 \%$, $3 \%$, respectively).

\section{DISCUSSION}

The prevalence of selected studies published in the last five years is associated with the growth in the number of researches for assessment of TB control interventions. The exception was 2017 , when this amount was minimal in relation to the previous two years, which may be related to the fact data collection was held while this year was still in progress.

A high number of studies published in English were identified. It should be noted that this language is considered universal for the dissemination of science, facilitating communication between researchers ${ }^{(42)}$. In what concerns the dissemination of the researches discussed here, this feature contributes to the dissemination of strategies across the planet and the consequent sharing of experiences of assessment of interventions for TB control.

The findings present a representative amount of studies published in countries considered developed, which may indicate a relationship with the availability of funding for scientific researches. Despite this, researches conducted in underdeveloped nations were also found, such as in Turkey, South Africa and Peru, which can also receive funding from international organizations such as the World Bank, which provides financial and technical support to low and medium-income countries, contributing permanently with global health and improving the health status of populations, which includes the control of $\mathrm{TB}^{(43)}$.

Most evaluation researches focused on quantitative approaches to the detriment of those of qualitative character. However, when the evaluation of health practices is proposed, the reach of the quantitative approach may not be sufficient for understanding the object under evaluation, it being necessary, according to the evaluative question chosen, to use the qualitative approach, or integrating them ${ }^{(44)}$.

The evidence allowed to observe that the evaluations mostly focused on TB control programs, which may be influenced by the constant commitments and actions of the United Nations, following the example of the End Tuberculosis Strategy, considering that, for the control of the disease, there is a need for consistent and coordinated interventions that generally use programmatic actions $^{(45)}$

The analysis of the evidence showed that the interventions evaluated integrate various aspects of TB control, although few studies focused on health education strategies were found. The contribution of these researches to the community in discussions related to signs, symptoms, transmission and treatment of the disease, in addition to the necessary care, are emphasized ${ }^{(3)}$. This finding was also identified in a study conducted in the state of Minas Gerais, southeastern Brazil, which stressed a lack of frequency in the realization of these activities ${ }^{(46)}$.

Several typologies were used to assess the interventions for TB control, which, despite having different nomenclatures, analyze the results produced only. This can be observed in the classification according to Avedis Donabedian's triad ${ }^{(8)}$, in which the evaluations of the results prevailed. These findings can be interpreted according to Tanaka ${ }^{(44)}$, for whom it is important to start the evaluation by the process, seeing as it is a moment when there is interaction between the services and the user with the possibility of the health practices being adjusted to best meet the needs of the context found.

It was identified that the evaluations were mostly performed at value judgement level, also called the third generation, when the merits of the proposed actions are analyzed. However, the need to consider the insertion of the users of interventions for TB control is emphasized, contributing to a participatory process proposed by the fourth generation evaluation ${ }^{(9)}$.

\section{Study limitations}

Limitations include the selection of databases, as studies addressing the topic may be found in other bases than those selected in this review. For future researches, the expansion in the number of databases is recommended, to supplement the results of this study. It should be noted that the lower percentage 
of studies published in 2017 is due to the fact that data collection was performed while this year was still ongoing.

\section{Contributions to the field of nursing, health, or public policy}

This study synthesized the existing evidence on the evaluation of interventions for the control of TB, shedding light on the knowledge about this subject to provide information that could divert the attention and practices of health professionals and managers in relation to controlling this condition and for the evaluation of these interventions.

\section{CONCLUSION}

The research made it possible to identify evidence on the evaluation strategies of interventions for TB control, which point mainly to programs focusing on the results dimension and on the third level of evaluation, judgement.

Interventions for the control of this pathology are performed around the world and their assessment provides information to aid in the decision making of managers, healthcare professionals and users of the services, which is essential for providing the desired results and contributing to the eradication of the disease.

\section{REFERENCES}

1. World Health Organization. Global tuberculosis report: 2017[Internet]. Geneva (CH): 2017[cited 2017 Nov 20]. Available from: http://apps. who.int/iris/bitstream/10665/259366/1/9789241565516-eng.pdf

2. Bayer R, Castro KG. Tuberculosis elimination in the United States: the need for renewed action. N Engl J Med [Internet]. 2017 [cited 2017 Nov 20];377:1109-11. Available from: http://www.nejm.org/doi/pdf/10.1056/NEJMp1707387

3. Maciel ELN, Sales CMM. Epidemiological surveillance of tuberculosis in Brazil: how can more progress be made? Epidemiol Serv Saúde [Internet]. 2016 [cited 2017 Nov 20];25(1):175-8. Available from: http://scielo.iec.gov.br/pdf/ess/v25n1/en_v25n1a18.pdf

4. Silva LMV, Formigli VLA. Health evaluation: problems and perspectives. Cad Saúde Pública [Internet]. 1994 [cited 2017 Nov 23];10(1):80-91. Available from: http://www.scielo.br/pdf/csp/v10n1/v10n1a09.pdf

5. Hopia H, Latvala E, Liimatainen L. Reviewing the methodology of an integrative review. Scand J Caring Sci [Internet]. 2016 [cited 2017 Sep 14];30(4):662-9. Available from: http://onlinelibrary.wiley.com/doi/pdf/10.1111/scs.12327

6. Santos CMC, Pimenta CAM, Nobre MRC. The PICO strategy for the research question construction and evidence search. Rev Latino-Am Enfermagem [Internet]. 2007 [cited 2018 Apr 25];15(3):508-11. Available from: http://www.scielo.br/pdf/rlae/v15n3/v15n3a23.pdf

7. Moher D, Liberati A, Tetzlaff J, Altman DG, PRISMA Group. Preferred reporting items for systematic reviews and meta-analyses: the PRISMA statement. PLoS Med [Internet]. 2009 [cited 2017 Sep 14];6(7):e1000097. Available from: https://www.ncbi.nlm.nih.gov/pmc/articles/ PMC2707599/pdf/pmed.1000097.pdf

8. Donabedian A. Evaluating the quality of medical care. Milbank Q [Internet]. 2005 [cited 2017 Oct 2];83(4):691-729. Available from: https:// www.ncbi.nlm.nih.gov/pmc/articles/PMC2690293/pdf/milq0083-0397.pdf

9. Furtado JP. [A constructivist method for health evaluation]. Ciênc Saúde Colet [Internet]. 2001 [cited 2018 Apr 25];6(1):165-81. Available from: http://www.scielo.br/pdf/csc/v6n1/7034.pdf Portuguese.

10. Wilson JW, Ramos JG, Castillo F, Castellanos EF, Escalante P. Tuberculosis patient and family education through videography in El Salvador. J Clin Tuberc Other Mycobact Dis [Internet]. 2016 [cited 2017 Aug 7];4:14-20. Available from: 10.1016/j.jctube.2016.05.001

11. Alkhalawi MJ, McNabb SJN, Assiri AM, Memish ZA. Evaluation of tuberculosis public health surveillance, Al-Madinah province, Kingdom of Saudi Arabia, 2012. J Epidemiol Glob Health [Internet]. 2016 [cited 2017 Aug 7];6(1):37-44. Available from: https://linkinghub.elsevier.com/ retrieve/pii/S2210-6006(15)00055-6

12. Guzzetta G, Ajelli M, Yang Z, Mukasa LN, Patil N, Bates JH, et al. Effectiveness of contact investigations for tuberculosis control in Arkansas. JTheor Biol [Internet]. 2015 [cited 2017 Aug 7];380:238-46. Available from: https://www.ncbi.nlm.nih.gov/pmc/articles/PMC4522372/pdf/nihms697517.pdf

13. Roque-Henríquez J, Catacora-López F, Hilasaca-Yungas G, Romaní-Romaní F. Evaluation of tuberculosis detection indicators in a region with high risk of transmission in Peru. Rev Peru Med Exp Salud Publica [Internet]. 2015 [cited 2017 Aug 8];32(3):504-8. Available from: https:// www.scielosp.org/pdf/rpmesp/2015.v32n3/504-508/es Spanish.

14. Mendonça AS, Franco SC. Evaluation of epidemiologic risk and Tuberculosis Control Program performance by health regions, State of Santa Catarina, Brazil, 2003-2010. Epidemiol Serv Saúde [Internet]. 2015 [cited 2017 Aug 8];24(1):59-70. Available from: http://www.scielo.br/pdf/ ress/v24n1/2237-9622-ress-24-01-00059.pdf Portuguese.

15. García de la Rosa RD, Davis Norales A, Rodríguez Rodríguez O, González Ochoa E. Quality control of follow-up of people in contact with tuberculosis carriers in Camagüey. MEDISAN [Internet]. 2014 [cited 2017 Aug 8];18(3):347-55. Available from: http://scielo.sld.cu/pdf/san/ v18n3/san08314.pdf Spanish.

16. Lima LM, Schwartz E, Cardozo Gonzáles RI, Harter J, Lima JF. The Tuberculosis Control Program in Pelotas/RS, Brazil: home contact investigations. Rev Gaúcha Enferm [Internet]. 2013 [cited 2017 Aug 8];34(2):102-10. Available from: http://www.scielo.br/pdf/rgenf/v34n2/en_v34n2a13.pdf

17. Heck MA, Costa JSD, Nunes MF. Evaluation of the tuberculosis program in Sapucaia do Sul, state of Rio Grande do Sul: indicators, $2000-2008$. Ciênc Saúde Coletiva [Internet]. 2013 [cited 2017 Aug 8];18(2):481-8. Available from: http://www.scielo.br/pdf/csc/v18n2/19.pdf Portuguese 
18. Arakawa T, Magnabosco GT, Andrade RLP, Brunello MEF, Monroe AA, Ruffino-Netto A, et al. Tuberculosis control program in the municipal context: performance evaluation. Rev Saúde Pública [Internet]. 2017 [cited 2017 Aug 9];51:23. Available from: http://www.scielo.br/pdf/rsp/ v51/0034-8910-rsp-S1518-87872016050006553.pdf

19. Karki B, Kittel G, Bolokon I Jr, Duke T. Active community-based case finding for tuberculosis with limited resources: estimating prevalence in a remote area of Papua New Guinea. Asia Pac J Public Health [Internet]. 2017 [cited 2017 Aug 9];29(1):17-27. Available from: https://www. ncbi.nlm.nih.gov/pmc/articles/PMC5349312/pdf/10.1177_1010539516683497.pdf

20. Dharan NJ, Blakemore R, Sloutsky A, Kaur D, Alexander RC, Ghajar M, et al. Performance of the G4 Xpert ${ }^{\oplus}$ MTB/RIF assay for the detection of Mycobacterium tuberculosis and rifampin resistance: a retrospective case-control study of analytical and clinical samples from high- and low-tuberculosis prevalence settings. BMC Infect Dis [Internet]. 2016 [cited 2017 Aug 9];16(1):764. Available from: https://www.ncbi.nlm.nih. gov/pubmed/27993132/pdf/12879_2016_Article_2039.pdf

21. McLaren ZM, Schnippel K, Sharp A. A data-driven evaluation of the Stop TB Global Partnership Strategy of targeting key populations at greater risk for tuberculosis. PLoS ONE [Internet]. 2016 [cited 2017 Aug 9];11(10):e0163083. Available from: http://journals.plos.org/plosone/ article/file?id=10.1371/journal.pone.0163083\&type=printable

22. Georghiou SB, Seifert M, Lin SY, Catanzaro D, Garfein RS, Jackson RL, et al. Shedding light on the performance of a pyrosequencing assay for drug-resistant tuberculosis diagnosis. BMC Infect Dis [Internet]. 2016 [cited 2017 Aug 9];16:458. Available from: https://www.ncbi.nlm.nih. gov/pubmed/27576542/pdf/12879_2016_Article_1781.pdf

23. Galarza M, Fasabi M, Levano KS, Castillo E, Barreda N, Rodriguez M, et al. High-resolution melting analysis for molecular detection of multidrug resistance tuberculosis in Peruvian isolates. BMC Infect Dis [Internet]. 2016 [cited 2017 Aug 9];16:260. Available from: https:// www.ncbi.nlm.nih.gov/pmc/articles/PMC4899911/pdf/12879_2016_Article_1615.pdf

24. Tans-Kersten J, Grace Lin SY, Desmond E, Warshauer D. Evaluating shared laboratory services: detecting Mycobacterium tuberculosis complex and drug resistance using molecular and culture-based methods. Public Health Rep [Internet]. 2016 [cited 2017 Aug 9];131(1):11725. Available from: https://www.ncbi.nlm.nih.gov/pmc/articles/PMC4716479/pdf/phr1310000117.pdf

25. Long R, Heffernan C, Gao Z, Egedahl ML, Talbot J. Do "virtual" and "outpatient" public health tuberculosis clinics perform equally well? a program-wide evaluation in Alberta, Canada. PLoS ONE [Internet]. 2015 [cited 2017 Aug 9];10(12):e0144784. Available from: http://journals. plos.org/plosone/article/file?id=10.1371/journal.pone.0144784\&type=printable

26. De Grass D, Manie S, Amosun SL. Effectiveness of a home-based pulmonary rehabilitation programme in pulmonary function and health related quality of life for patients with pulmonary tuberculosis: a pilot study. Afr Health Sci [Internet]. 2014 [cited 2017 Aug 9];14(4):866-72. Available from: https://www.ncbi.nlm.nih.gov/pmc/articles/PMC4370065/pdf/AFHS1404-0866.pdf

27. Chua AP, Lim LK, Ng H, Chee CB, Wang YT. Outcome of a grocery voucher incentive scheme for low-income tuberculosis patients on directly observed therapy in Singapore. Singapore Med J [Internet]. 2015 [cited 2017 Aug 9];56(5):274-9. Available from: https://www.ncbi.nlm.nih. gov/pmc/articles/PMC4447929/pdf/SMJ-56-274.pdf

28. Wang L, Mohammad SH, Chaiyasirinroje B, Li Q, Rienthong S, Rienthong D, et al. Evaluating the Auto-MODS assay, a novel tool for tuberculosis diagnosis for use in resource-limited settings. J Clin Microbiol January [Internet]. 2015 [cited 2017 Aug 9];53(1):172-8. Available from: http://jcm.asm.org/content/53/1/172.full.pdf

29. Azman AS, Golub JE, Dowdy DW. How much is tuberculosis screening worth? estimating the value of active case finding for tuberculosis in South Africa, China, and India. BMC Med [Internet]. 2014 [cited 2017 Aug 9];12:216. Available from: https://bmcmedicine.biomedcentral. com/track/pdf/10.1186/s12916-014-0216-0

30. Birch E, Andersson M, Koch A, Stenz F, Søborg B. Ten years of tuberculosis intervention in Greenland: has it prevented cases of childhood tuberculosis? Int J Circumpolar Health [Internet]. 2014 [cited 2017 Aug 9];73:24843. Available from: https://www.ncbi.nlm.nih.gov/pmc/ articles/PMC4095760/pdf/IJCH-73-24843.pdf

31. Blaya JA, Shin SS, Yagui M, Contreras C, Cegielski P, Yale G, et al. Reducing communication delays and improving quality of care with a tuberculosis laboratory information system in resource poor environments: a cluster randomized controlled trial. PLoS One [Internet]. 2014 [cited 2017 Aug 9];9(4):e90110. Available from: https://www.ncbi.nlm.nih.gov/pmc/articles/PMC3982951/pdf/pone.0090110.pdf

32. Turk T, Newton FJ, Netwon JD, Naureen F, Bokhari J. Evaluating the efficacy of tuberculosis Advocacy, Communication and Social Mobilization (ACSM) activities in Pakistan: a cross-sectional study. BMC Public Health [Internet]. 2013 [cited 2017 Aug 9];13:887. Available from: https://bmcpublichealth.biomedcentral.com/track/pdf/10.1186/1471-2458-13-887

33. Cass A, Shaw T, Ehman M, Young J, Flood J, Royce S. Improved outcomes found after implementing a systematic evaluation and program improvement process for tuberculosis. Public Health Rep [Internet]. 2013 [cited 2017 Aug 9];128(5):367-76. Available from: https://www. ncbi.nlm.nih.gov/pmc/articles/PMC3743285/pdf/phr128000367.pdf

34. Yang YR, McManus DP, Gray DJ, Wang XL, Yang SK, Ross AG, et al. Evaluation of the tuberculosis programme in Ningxia Hui Autonomous region, the People's Republic of China: a retrospective case study. BMC Public Health [Internet]. 2012 [cited 2017 Aug 9];12:1110. Available from: https://bmcpublichealth.biomedcentral.com/track/pdf/10.1186/1471-2458-12-1110

35. Khan K, Mustafa Hirji M, Miniota J, Hu W, Wang J, Gardam M, et al. Domestic impact of tuberculosis screening among new immigrants to Ontario, Canada. CMAJ [Internet]. 2015 [cited 2017 Aug 9];187(16):E473-E481. Available from: http://www.cmaj.ca/content/cmaj/ early/2015/09/28/cmaj.150011.full.pdf

36. Yasin Y, Biehl K, Erol M. Infection of the invisible: impressions of a tuberculosis intervention program for migrants in Istanbul. J Immigr 
Minor Health. CMAJ [Internet]. 2015 [cited 2017 Aug 9];17(5):1481-6. Available from: https://link.springer.com/article/10.1007\%2 Fs10903-014-0115-7

37. Velayutham B, Thomas B, Nair D, Thiruvengadam K, Prashant S, Kittusami S, et al. The usefulness and feasibility of obile Interface in Tuberculosis Notification (MITUN) voice based system for notification of tuberculosis by private medical practitioners: a pilot project. PLoS One [Internet]. 2015 [cited 2017 Aug 9];10(9):e0138274. Available from: http://journals.plos.org/plosone/article/file?id=10.1371/journal. pone.0138274\&type=printable

38. Salyer SJ, Fitter DL, Milo R, Blanton C, Ho JL, Geffrard H, et al. Evaluation of the national tuberculosis surveillance program in Haiti. Int J Tuberc Lung Dis [Internet]. 2015 [cited 2017 Aug 9];19(9):1045-50. Available from: https://www.ncbi.nlm.nih.gov/pmc/articles/ PMC4684091/pdf/nihms-743577.pdf

39. Podewils LJ, Bantubani N, Bristow C, Bronner LE, Peters A, Pym A, et al. Completeness and reliability of the Republic of South Africa national tuberculosis (TB) surveillance system. BMC Public Health [Internet]. 2015 [cited 2017 Aug 9];15:765. Available from: https://bmcpublichealth. biomedcentral.com/track/pdf/10.1186/s12889-015-2117-3

40. Van Kampen SC, Susanto NH, Simon S, Astiti SD, Chandra R, Burhan E, et al. Effects of introducing Xpert MTB/RIF on diagnosis and treatment of drug-resistant tuberculosis patients in Indonesia: a pre-post intervention study. PLoS One [Internet]. 2015 [cited 2017 Aug 9];10(6): e0123536. Available from: http://journals.plos.org/plosone/article/file?id=10.1371/journal.pone.0123536\&type=printable

41. Oliveira LGD, Natal S, Camacho LAB. [Analysis of the implementation of the Tuberculosis Control Program in Brazilian prisons]. Cad Saúde Pública [Internet]. 2015 [cited 2017 Aug 9];31(3):543-54. Available from: http://www.scielo.br/pdf/csp/v31n3/0102-311X-csp-31-03-00543. pdf Portuguese.

42. Drubin DG, Kellogg DR. English as the universal language of science: opportunities and challenges. Mol Biol Cell [Internet]. 2012 [cited 2018 Apr 25];23(8):1399. Available from: https://www.ncbi.nlm.nih.gov/pmc/articles/PMC3341706/pdf/1399.pdf

43. Sridhar D, Winters J, Strong E. World Bank's financing, priorities, and lending structures for global health. BMJ [Internet]. 2017 [cited 2017 Nov 23];358:j3339. Available from: http://www.bmj.com/content/bmj/358/bmj.j3339.full.pdf

44. Tanaka OY. [Primary health care evaluation: a new approach]. Saúde Soc [Internet]. 2011 [cited 2017 Nov 23];20(4):927-34. Available from: http://www.scielo.br/pdf/sausoc/v20n4/10.pdf Portuguese.

45. Petersen E, Maeurer M, Marais B, Migliori GB, Mwaba P, Ntoumi F, et al. World TB day 2017: advances, challenges and opportunities in the "end-TB" era. Int J Infect Dis [Internet]. 2017 [cited 2017 Oct 31];56:1-5. Available from: http://www.ijidonline.com/article/ S1201-9712(17)30059-0/pdf

46. Andrade HS, Oliveira VC, Gontijo TL, Pessôa MTC, Guimarães EAA. Evaluation of Tuberculosis Control Program: a case report. Saúde Debate [Internet]. 2017 [cited 2017 Nov 23];41(spe):242-58. Available from: http://www.scielo.br/pdf/sdeb/v41nspe/0103-1104-sdeb-41-nspe-0242. pdf Portuguese. 